Originalveröffentlichung in: Rotberg, Robert I. ; Rabb, Theodore K. (Hrsgg.): Art and history : images and their meaning, Cambridge 1988, S. 39-65

Christoph L. Frommel

\title{
Papal Policy: The Planning of Rome during the
}

Renaissance The investigation of patronage and town planning has become increasingly important for our understanding of the history of architecture and in particular for the history of Roman Renaissance architecture. The projects of individual popes have been thoroughly analyzed, but no attempt has been made to look at papal building policy during the Renaissance as a whole, to find out its principal motives, or to distinguish between continuous and discontinuous forces. This article suggests that much of the unique beauty of Renaissance Rome is the result of the particular character of papal government. ${ }^{1}$

The center of the old city of Rome differs from that of other Italian towns in that it has two centers of gravity: the Vatican and the Capitol. Until roo years ago both were situated on the periphery of the city. The Capitol, which since the Middle Ages had been the seat of the communal administration, only attained its present representative character during the sixteenth and seventeenth centuries and earlier was anything but impressive. Even before its recent isolation from the rest of the city was achieved by archaeologists and patriots seeking to preserve its character, it did not play a role comparable to that of the urban centers of Venice, Florence, Siena, or other smaller towns. The Vatican, at

Christoph L. Frommel is Director of the Bibliotheca Hertziana in Rome. He is a co-author of Raffaello architetto (Milan, 1984).

An earlier version of the article was presented at the Congress of the Istituto Gramsci in 1983 and a revised version appeared in Italian in C. De Seta (ed.), Le cittá capitali (Rome, 1985), 95-IIO. The author thanks Julian Gardner for assistance with the English text of this article.

I On Roman Renaissance urbanism in general, see Gustavo Giovannoni, "Roma dal Rinascimento al 1870 ," in Ferdinando Castagnoli et al., Topografia e urbanistica di Roma (Rome, 1958), 343-420, 499-517; Torgil Magnuson, Studies in Roman Quattrocento Architecture (Rome, I958), 3-2I I; Frommel, Der römische Palastbau der Hochrenaissance (Tübingen, I973), I, II-24; Luigi Spezzaferro, "Place Farnèse: urbanisme et politique," in Ecole française de Rome (eds.), Le Palais Farnèse (Rome, I98I), I, I, 85-123; Manfredo Tafuri, "Roma instaurata. Strategie urbane e politiche pontificie nella Roma del primo cinquecento," in Frommel et al., Raffaello architetto (Milan, I984), 59-106. 
the opposite end of the city, dominates the area. Suffice it to compare the scale of its square with that of the Campidoglio.

This dual structure of the city reflects its uncommon urban history: whereas in Venice, Mantua, or Urbino the communal and the spiritual centers of the town are more or less identical, and in Florence, Siena, or Milan one needs just a few minutes to move from one to the other, in Rome such a walk would take about half an hour. And if the Roman cathedral of St. John Lateran-a church which has been completely on the periphery since the early Renaissance-is included as a third point of gravity, the circle becomes even larger.

This uncommon urban structure, together with a series of atypical urban phenomena, is the result of a development which started long before the exile of the popes to Avignon. But it became permanent only after their return at the beginning of the Renaissance. This article concentrates on the period between Nicholas V, whose main architectural adviser was Leon Battista Alberti, and Pius IV, who commissioned Michelangelo to execute the Piazza del Campidoglio in I 560.

Before Nicholas V started his vast Vatican building schemes soon after his election in 1447 , he must have debated whether the Vatican should really be the papal residence-and not the Lateran palace, the traditional seat of the Roman bishop. But there was probably no real dispute. The Lateran was a distance from the town and partly in ruins, whereas the medieval, fortified residence on Vatican hill and old St. Peter's were still intact. St. Peter's had become the far more important of the two basilicas. As if to stress the bipolarity of the city, Nicholas commissioned, in the first year of his reign, the modernization of both the Capitol and the Vatican palace. $^{2}$

A huge northern wing, which overlooked the splendid gardens and served as the private apartment of the popes, was added to the Vatican palace early in Nicholas' reign. Its rooms were richly decorated with mosiac floors, stained glass windows, and frescoes, later to be replaced by those of Pinturicchio and Raphael. The stern and sober exterior, with its tower, scarp, and crenella-

2 Carroll William Westfall, In This Most Perfect Paradise (London, 1974), 94-101, 129I65. 
tion, still followed the pattern of a medieval fortress. This stark exterior, contrasting with the lavish interior, was to remain a characteristic of papal buildings for at least another sixty years. The popes, recently returned from a traumatic exile, did not feel entirely safe. Danger threatened not only from outside, but also from the different warring factions within the city. The northern wing of the Vatican palace was unexciting both because of its fortress-like character and because its architect, the justly unknown Antonio da Firenze, was a good engineer, but not a great artist. $^{3}$

Only in $145 \mathrm{I}$, when the huge peperino tower and part of the Vatican fortifications had already been executed, did the far more modern Bernardino Rossellino arrive from Florence and immediately start rebuilding St. Peter's. The project was apparently his, but a year later work was interrupted on the advice of the great Alberti. Alberti, who had been scriptor brevium (papal writer) since the pontificate of Eugene IV and was on friendly terms with both popes, was then finishing his great treatise, "De re aedificatoria," which he dedicated to Nicholas V in 1452 . Thus Nicholas' famous building program, which we know of only from Giannozzo Manetti, his posthumous biographer, and which is imbued with Albertian ideas, was formulated only between 1452 and Nicholas' death in I455. Many popes, like Nicholas, only succeeded in establishing a coherent building policy after having been in power for some time. ${ }^{4}$

This building program, which has been reconstructed, interpreted, and repeatedly discussed, is important not only for the beginning of Roman town planning, but also for the city's subsequent development. Nicholas $\mathrm{V}$ believed, as did Alberti, that architecture had a highly political impact. "Not for ambition," Nicholas said on his deathbed, "nor pomp, nor vainglory, nor fame, nor the eternal perpetuation of my name, but for the greater authority of the Roman church and the greater dignity of the Apostolic See... we conceived such buildings in mind and

3 Eugène Müntz, Les arts a la cour des papes (Paris, I878), I, I II-I I2; Magnuson, Roman Quattrocento, 91 -92 .

4 See Westfall, Perfect Paradise, 167, for a different opinion. But Michael Canensius, in a biography of Nicholas, does not mention any of the particularly Albertian aspects of Nicholas' building program: Ad beat. D.N. Nicolaum V Pont. Max., Cod. Lat. Vat. 3697 , Biblioteca Vaticana. 
spirit." He may have become aware of this lack of buildings which attested to the dignity of the Roman church when, during the Holy Year of 1450 , thousands of pilgrims found the architecture of Rome much inferior to that of central and northern Italian towns. In 1452 , however, the emperor Frederick III may well have been greatly impressed by the beginnings of Nicholas' new buildings, which were far more monumental than anything then existing in Vienna. ${ }^{5}$

The more relevant aspect for Roman urbanism of this building program was not so much the papal palace, with its marble theater, its huge library and stables, the atria, or the dining and assembly halls, but the idea of connecting the square in front of Castel Sant'Angelo with St. Peter's Square by three straight and wide modern streets. Each of them was to be flanked by houses with shops on the ground floors and apartments above, the hierarchically most important central street being reserved for the highest class of merchants and artisans, the right one for the intermediate, and the left one for the lowest class. This rational system of regular streets, found already in newly planned medieval towns such as Scarperia, was realized neither under Nicholas nor thereafter. ${ }^{6}$

For centuries every sort of systematic, long-range plan for Rome came to naught. The primary reason was the high degree of egocentrism behind subsequent papal building activity-an egocentrism which would have been impossible in a democratic commune or even in states with a continuous dynasty. The popes were elected and frequently came from unimportant families; often they were aged and had only a few years more to live. Thus they had no time to lose if they wanted to do something for their own glory and for the future of their own lineage. Many of them, being humanists, were often, at least during the Renaissance, better trained to be patrons than the average prince or community leader; they were also more eager to emulate the traditional approach to art and architecture. Had they been guided, at least in part, by Nicholas' sense of altruistic responsibility and his sound long-range building program, the layout of Renaissance Rome would have become more coherent and more similar to that of

5 Westfall, Perfect Paradise, 33.

6 Magnuson, Roman Quattrocento, 55-97. 
Florence or Siena. But there would also have been fewer outstanding architectural monuments.

Nicholas' successor, Calixtus III, did not start any building of interest. But the first important postmedieval private palace of Rome, the still existing Palazzo Sforza Cesarini, was begun by his favorite nephew, Rodrigo Borgia, who later became Alexander VI. Rodrigo had been named cardinal when he was twentysix years old and vice-chancellor, the most important position after the pope, when he was twenty-eight. His palace, situated prominently on Via dei Banchi Vecchi, one of the main streets in the center of the city, was the first of a long series of palaces built by papal relatives which imbued Rome with much of its splendor. Its exterior tower and /crenellation followed, as had Nicholas' Vatican wing, the pattern of castles and fortresses; the large courtyard, with its porticoes and garden, provided the owner with the comforts of the new age. ${ }^{7}$

Pius II Piccolomini, Calixtus' successor, was another great humanist and had actively collaborated in Nicholas' attempt to reestablish the Roman papacy. He was also in close contact with Alberti, who accompanied him when he made a long trip to Mantua after his election. This trip had two important results for the history of architecture: the foundation of the town of Pienza, and Alberti's first entirely new building, San Sebastiano in Mantua. It would have been much more logical had Pius continued Nicholas' building program for Rome, and it would have been equally logical had Pius appointed Alberti to execute what may have been partly his program. Instead Alberti left Rome for Mantua to serve Lodovico Gonzaga from I 459 to I 463 and from I 470 to I47I, and Rossellino instead was commissioned to build Pienza. ${ }^{8}$

This development was more a series of unplanned coincidences and spontaneous decisions than the result of a conscious change in building policy. It is unlikely that Pius II knew whether or what he would build in Pienza when he left Rome in 1458 to

7 Ludwig von Pastor, Geschichte der Päpste seit dem Ausgang des Mittelalters (Freiburg, 1925; rev. ed.), I, 759-767; Magnuson, Roman Quattrocento, 230-239.

8 Pastor, Geschichte der Päpste (1894; rev. ed.), II, I4-34; Girolamo Mancini, Vita di Leon Battista Alberti (Florence, I9I I), 382-393; Guido Guidetti, "Leon Battista Alberti direttore della Fabbrica di San Sebastiano," in Il Sant'Andrea di Mantova e Leon Battista Alberti (Mantua, 1974), 237-24I. 
organize a crusade against the Turks. But when he arrived at his native Corsignano and witnessed its misery, he saw in it the opportunity both to eternalize his memory and to realize an architectural utopia impossible in Rome with all its existing buildings and traditions. Unlike Nicholas $\mathrm{V}$, his primary incentive was not to relieve the misery of the population, acquire material profit, or encourage religious devotion, but rather to enhance his own glory as was the intention of other great patrons of the period. A similarly egocentric approach is evident in the papal building policy of the next century, whether in Rome or elsewhere. ${ }^{9}$

Immediately upon his return from Mantua, in the autumn of I 460 , Pius commissioned the renewal of St. Peter's Square. Its main facade was to be an eleven-bay, two-storied Loggia of Benediction in white marble, with antique columns in front of its pillars and huge classic-styled stairs (Fig. I). As architect he chose a hitherto unknown and since forgotten humanist and papal financial officer, Francesco del Borgo, whose ideas turned out to be closer to Alberti's than those of any other contemporary. ${ }^{10}$

Francesco was the first directly to imitate the massive structure of Roman exteriors, such as the Tabularium or the Coliseum. Thus he became the founder of Roman Renaissance architecture as opposed to the more abstract Tuscan Renaissance of Filippo Brunelleschi, Michelozzo, or Rossellino. The classical character of Pius II's Loggia of Benediction and its prominent urbanistic role as the main façade looking into the most important square of Christianity marks a decisive change in approach toward antiquity when compared to Pope Nicholas' more fortress-like project. His more advanced notions may also explain why he did not continue Nicholas' heavy and inelegant project for St. Peter's. Instead he began religious buildings, such as the chapels for the head of St. Andrew which had arrived during his pontificate from the east and which was meant to symbolize a reunification with the Christian past. There can be no doubt that his building policy was increasingly inspired by religious motives.

A similar lack of continuity in papal building policy was evident after Pius' death in I464, when another great patron, Paul

9 Enea Silvio Piccolomini (ed. Luigi Totaro), I Commentarii, lib. II, cap. 20 (Milan, I984), I, 3 I4.

Io Frommel, "Francesco del Borgo: Architekt Pius' II. und Pauls II.: Pt. I," in Römisches Jahrbuch für Kunstgeschichte, XX (1983), 107-154. 
Fig. 1 Reconstruction of Pope Pius II's Loggia of Benediction, St. Peter's Square, Rome.

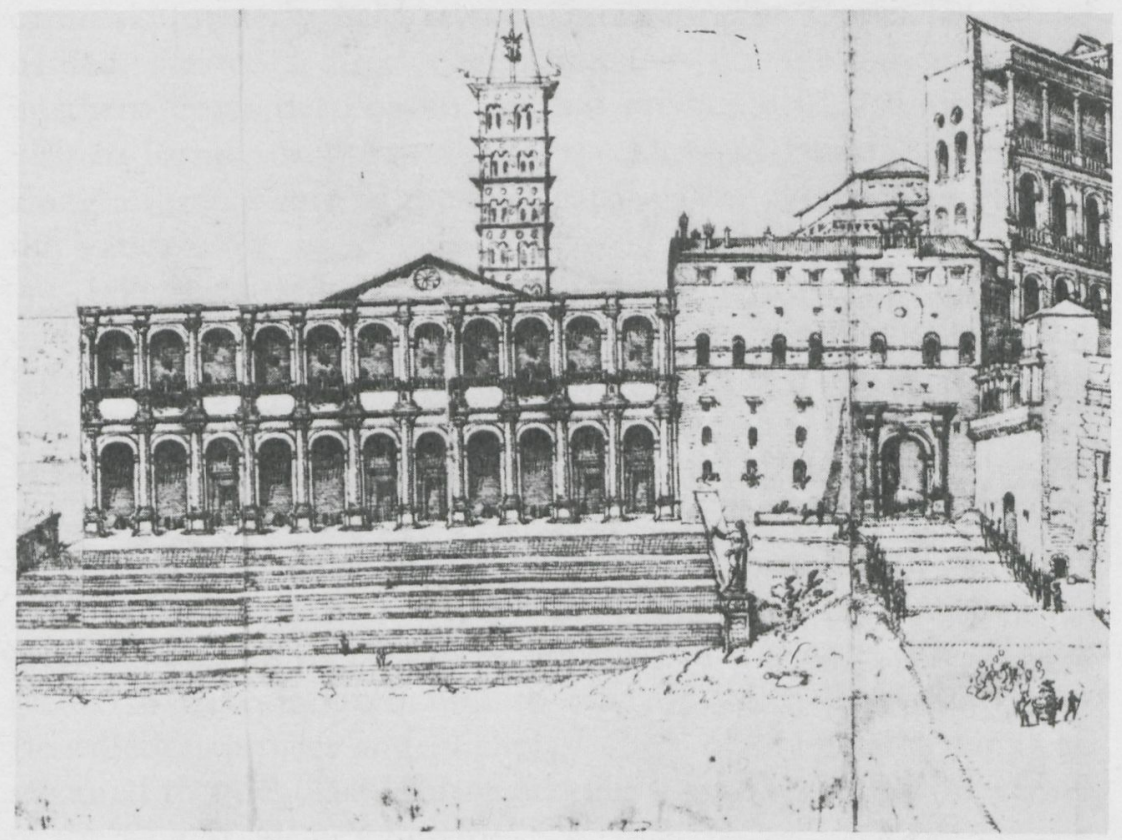

II Barbo, succeeded him. Although the next holy year of I475 was approaching, Paul II left both Pius' and Nicholas' buildings unfinished and concentrated instead on a completely different project: the transformation of the palace that he had occupied as a cardinal near San Marco into a second papal residence (Fig. 2). His architect was the same Francesco del Borgo who had begun the Loggia of Benediction. Again the fortress-like exterior of the palace had little to do with the humanistic articulation of the Palazzi Rucellai or Piccolomini; all Renaissance splendor was concentrated in the interior with its classically styled courtyard, vestibule, hanging garden, staircases, and monumental halls. Paul's motives were rather obvious: like Pius he did not want to be the anonymous follower of his predecessor but longed for personal glory, as had Pius at Pienza. Venetian born, he wanted to confer a new importance on San Marco, the patron saint of his former titular church; and building was a passion in itself. His intention, ultimately realized, was to enjoy a comfortable life which, in the 
Fig. 2 Palazzo Venezia, Rome. Reconstruction Project of 1465.

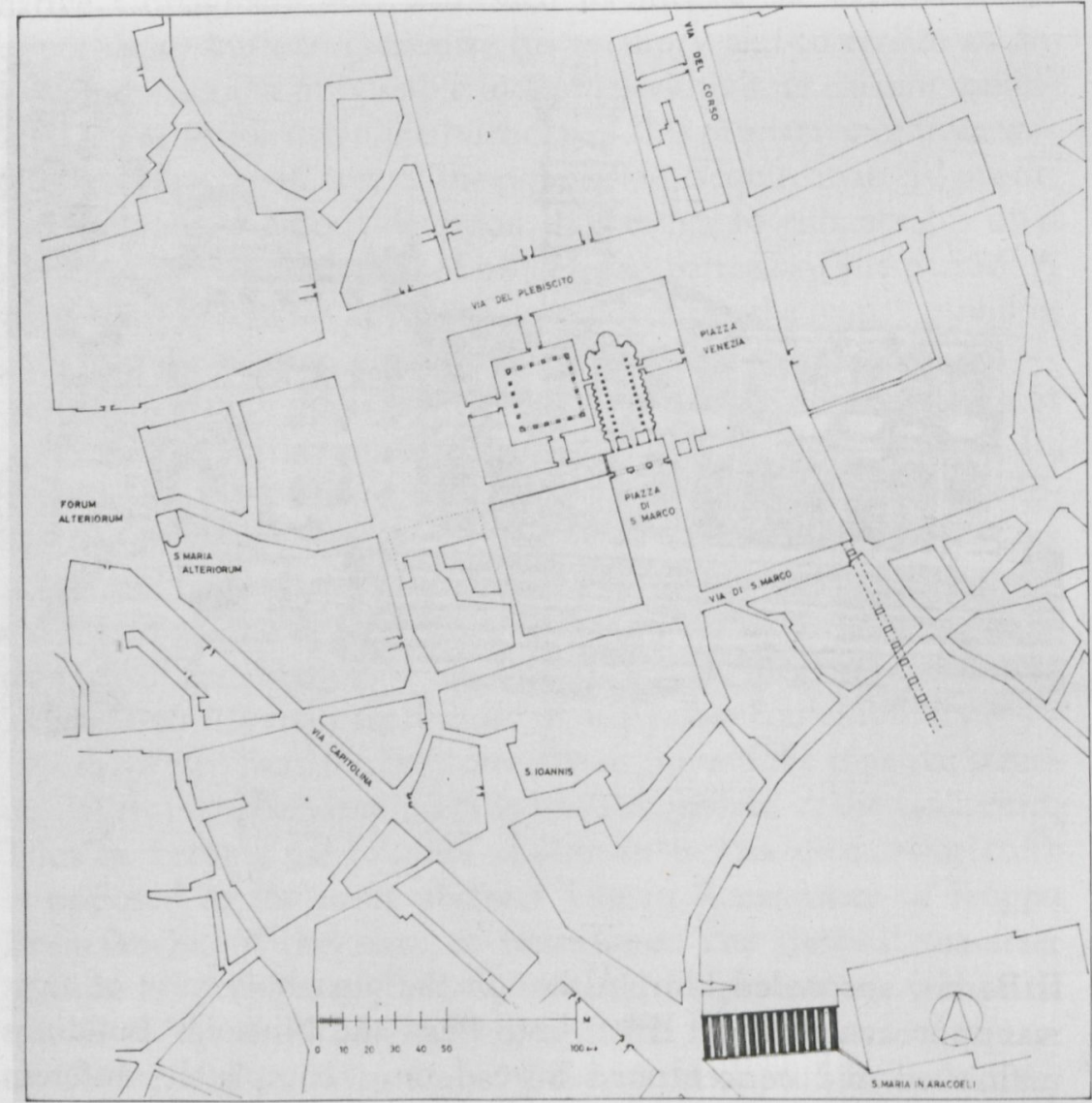

SOURCE: Drawing by Emanuela von Branca in Römisches Jahrbuch für Kunstgeschichte, XXI (1984), 125, Fig. 23.

dark Vatican, much gloomier than a modern palace, was more difficult. ${ }^{11}$

For the further development of Roman urbanism by far the most important goal was Paul's wish to establish the papal residence "in centro urbis" near the Forum and the Capitol. Paul tried to establish curial offices and install wealthy merchants around the two new squares which were laid out in front of San Marco 
and the palace. He reopened the antique Via Flaminia, which had been partly blocked by medieval buildings, to accommodate the carnival, formerly held at the Testaccio. The Corso, as it was named, created a direct connection between the palace and the northern Porta del Popolo, so that Frederick III, on his second visit to Rome, or Borso d'Este, the Duke of Ferrara, could ride along a direct route to the new papal palace even before visiting the Vatican. ${ }^{12}$

Like the first building activities of Nicholas and Pius, those of Paul also, after some years, reached a critical juncture. Paul felt himself threatened by a group of humanists associated with Pomponio Leto, who were wrongly suspected of conspiracy. Paul believed that members of Leto's circle had hidden themselves in the unfinished parts of his new palace, which thus proved to be highly insecure. After Francesco's death that same year, I468, the pope returned to the safety of the Vatican and concentrated increasingly on its renewal. The approach of the holy year of I 475 seems to have induced him to take up again Pius' Loggia of Benediction project and Nicholas' choir of St. Peter's. He even returned to Nicholas' idea of making Caesar's obelisk the center of the new St. Peter's Square.

No sooner was Paul succeeded by Sixtus IV della Rovere (I47I-I484), a Franciscan, than papal building policy once again changed completely. Sixtus was less hedonistic and a much more pragmatic and functional patron. Instead of spending his money on a few costly monuments, he tried-the first of all post-medieval popes to do so-to create a sound urban system of roads and bridges, hospitals, churches, and chapels - the last mostly dedicated to the Virgin. He replaced the old Vatican Capella Magna with the spacious but again fortress-like Capella Sistina and began, next to the atrium of St. Peter's, a huge building to house the most important offices of the curia. ${ }^{13}$

I2 Idem, "Chi era l'architetto di Palazzo Venezia?" in Silvana Nacchioni and Bianca Tavassi La Greca (eds.), Studi in onore di Giulio Carlo Argan (Rome, 1984), II, 44.

I3 James S. Ackerman, "Rome in the Renaissance: The City and the Myth," in Paul A. Ramsey (ed.), Papers of the Thirteenth Annual Conference of the Center for Medieval and Early Renaissance Studies (New York, 1982), 7-II; Tilman Buddensieg, "Die Statuenstiftung Sixtus' IV. im Jahre I47I," in Römisches Jahrbuch für Kunstgeschichte, XX (1983), 54-72; Maria Luisa Madonna and Anna Maria Cerioni, "Momenti della politica edilizia e urbanistica dello Stato Pontificio nel '40o. L'exemplum della Piazza del Comune a Viterbo," in Roberto Cannata and Claudio Strinati (eds.), Il Quattrocento a Viterbo (Rome, 1983), 2389. 
But Sixtus would not have been the follower of Calixtus, Pius, and Paul had he concentrated exclusively on the needs of the church and the holy year. He apparently supported the enormous building activity of his many kinsmen who began to construct huge palaces in such different places of the city as San Pietro in Vincoli, Santi Apostoli, Sant'Apollinare, and Piazza Scossacavalli. Other cardinals, such as Guillaume d'Estouteville, the rich chamberlain, built Sant'Agostino and its adjacent palace. Each of these palaces had its own square and was connected as directly as possible to the older street system. Their effect on Roman urbanism was, on a smaller scale, similar to what had happened around Palazzo Venezia: the new palaces and churches became radiating centers of urban renewal. Sometimes there was the danger that different street systems conflicted, as happened with the Palazzo Farnese, where the axial access, the Via dei Baullari, did not harmonize with the older street system around the Cancelleria. The authority of the responsible urban planners, the maestri di strada and their architects, was not as strong as the egocentrism of papal kinsmen. ${ }^{14}$

If, under Sixtus, churches and public institutions were still equally important, further development favored the private palaces. It is symptomatic that Sixtus' nephew and new chamberlain, the young Raffaele Riario, could destroy the famous early Christian basilica of San Lorenzo in Damaso and incorporate its successor invisibly in the large body of his palace. Nearly every Renaissance pope concentrated just on his secular residences and thought only subsequently of ecclesiastical building.

Riaro, in close contact since his early youth with the great humanists of his time, was the first Roman patron to eschew a fortress-like exterior for his new palace. This was not so much a question of function as of appearance, since the Cancelleria, his residence, was equally safe and was built with fortified cornerrooms. Its exterior surpassed even the standards of the Palazzi Rucellai and Piccolomini. It was, however, a long time before

I4 Günther Urban, "Die Kirchenbaukunst des Quattrocento zu Rom," in Römisches Jahrbuch für Kunstgeschichte, IX/X (I961/62), 274-276. Sixtus' two famous bulls were meant to stimulate the building of sumptuous palaces, and showed the strong influence of nepotism. The bull of 1475 allowed prelates to leave a palace or country house near Rome to relatives even if it had been built with income from the church; the second bull, of I 480 , enabled builders of sumptuous palaces to incorporate adjacent land or houses: Müntz, Les arts (I882), III, I80-187. Spezzaferro, "Place Farnèse," I1 5-I23. 
others followed his new pattern. This conservative phase resulted partly from the lack of first-rate architects and partly from Sixtus IV's interest in quantity rather than in the quality of architecture. Only at the end of his pontificate did the arrival in Rome of Baccio Pontelli herald a change in style. Pontelli was a young Florentine who had been trained in Urbino and may have designed not only the castles of Ostia and Grottaferrata but also the Cancelleria, the belvedere of Innocent VIII, Santa Aurea in Ostia, and San Pietro in Montorio-all of them representing a more refined and classical style. ${ }^{15}$

Sixtus' successor, Innocent VIII Cibo, was not a great builder, but his Belvedere, on the northern slope of the Vatican hill, was the first real Roman villa. It was no accident that it was more or less contemporary with the Cancelleria. Although apparently part of the Vatican fortification, it opened onto the landscape as did its famous prototypes in Florence and Urbino. But, as in the case of the Urban palace, it was many years before the open, outwardlooking villa in Rome became an aim of the architecture of the great masters. ${ }^{16}$

This delay was partly a consequence of the personality and policy of Rodrigo Borgia, Innocent's successor on the papal throne from I494 to I503. As Alexander VI he did not dare to build open palaces or villas. He tried primarily to guarantee his own and his family's security by strengthening the fortifications of Castel Sant' Angelo, adding the strong Torre Borgia to the Vatican apartment, and by building such impressive fortresses as that at Civita Castellana. The latter was by far the most important building project of his pontificate. Again, the stern exteriors of these buildings were balanced by the splendor of their interiorsbe it the beautiful courtyard at Cività Castellana, Pinturicchio's frescoes of almost oriental splendor in the Appartamento Borgia, or the gilded ceiling of Santa Maria Maggiore. ${ }^{17}$

Alexander's preparations for the important jubilee of I500 were astonishingly modest. He did not finish either Pius' Loggia

Is Armando Schiavo, Il palazzo della Cancelleria (Rome, 1963), 37-62; Frommel, "Raffaele Riario e la Cancelleria," unpub. ms. (1985); idem, Palazzi Romani del Rinascimento, forthcoming; idem, "Chi era l'architetto?" $5 \mathrm{I}$.

I6 Dioclecio Redig de Campos, I palazzi Vaticani (Bologna, 1967), 7I-78; David R. Coffin, The Villa in the Life of Renaissance Rome (Princeton, I979), 240-279.

I7 Redig de Campos, I palazzi Vaticani, 8I-85; Frommel, "Raffael und Antonio de Sangallo der Jüngere," in Raffaello a Roma (Rome, 1986), 262-266. 
of Benediction or the Via Alessandrina, one of the two new streets between Castel Sant' Angelo and St. Peter's Square which had already been planned by Nicholas V. Only in February I499, ten months before the arrival of the pilgrims, did he decide to open this straight, wide street which-characteristically-led directly to the portal of the palace-and not to that of St. Peter's. All houses in the way were demolished without regard to their owners, who were obliged within two months to build new houses at least 15.63 meters high along the street. If they did not obey, the ground was to be sold by the Camera Apostolica to willing builders. ${ }^{18}$

Via Alessandrina was, not by accident, the first artificially straight street since the days of ancient Rome. Nicholas V had planned such streets but never realized them, and not even Sixtus IV had dared to undertake the necessary demolitions. But Alexander's ruthless example was followed by many of his successors and thus with him opened the authoritarian age of Roman urbanism. One of its most powerful representatives was Julius II ( $\mathrm{I}_{503}-$ I5I3), who succeeded Alexander after the short interlude of Pius III. Giuliano della Rovere, Pope Julius II, was the nephew and protégé of Sixtus IV and already, as a cardinal, a patron of such important architects as Baccio Pontelli and Giuliano da Sangallo. Immediately after his election he appointed Donato Bramante his first architect-Bramante, the most talented architect of his generation, who had come voluntarily to Rome after the fall of Milan but had not received any large commission from Alexander VI. Following the pattern of earlier Renaissance popes, Julius did not touch the unfinished Via Alessandrina-which was only completed by Leo $\mathrm{X}$-and soon moved out of the residence of his hated predecessor. ${ }^{19}$

Julius did try, however, to transform the nepotism and dynastic imperialism of the Borgias into a papal policy with the goal I8 Frommel, "Francesco del Borgo," I, I23; Marcello Fagiolo, "Arche-tipologia della piazza di S. Pietro," in idem and Gianfranco Spagnesi (eds.), Immagini del Barocco: Bernini e la cultura del Seicento (Rome, I982), I I7-132; Madonna, "Una operazione urbanistica di Alessandro VI: La via Alessandrina in Borgo," in Maurizio Calvesi (ed.), Le arti a Roma sotto Alessandro VI (Rome, I98I), 4-9.

I9 Pastor, Geschichte der Päpste (1924; rev. ed.), III, 896-953; Frommel, "Capella Iulia: Die Grabkapelle Papst Julius' II. in Neu-St. Peter," in Zeitschrift fur Kunstgeschichte, XL (1977), 26-62; Loren Partridge and Randolph Starn, A Renaissance Likeness: Art and Culture in Raphael's Julius II (Berkeley, I980), 37-4I; Frommel, "Il Palazzo Vaticano sotto Giulio II e Leone X. Strutture e funzioni," in Raffaello in Vaticano (Milan, 1984), 123. 
of reunifying Italy under the papal flag. Again his first commission was a secular building, the famous Cortile del Belvedere. Julius probably had first insisted on a viaduct between the old palace and Innocent VIII's villa, and it was certainly Bramante's idea to transform the whole intermediate area into an enormous villa (Fig. 3). It was unrivaled in size by any Renaissance building and thus became the adequate expression of the pope's imperial ambitions. His ambition was also clearly expressed in the unjustly ignored foundation medal, the inscription of which compared the project with Nero's Domus Transitoria. ${ }^{20}$

The survival of his name on earth and the reception of his soul in heaven was the subject of Julius' great funeral monument, begun by Michelangelo early in I 505 . Only when he considered placing the monument in the choir of St. Peter's, started by Nicholas $\mathrm{V}$ but never finished, did Bramante and others persuade Julius to rebuild the whole of St. Peter's. This project required so much money and artistic energy that the Cortile del Belvedere was neglected and work on the tomb completely abandonedanother characteristic case of irrational and spontaneous papal building policy. Only a year after the foundation of the new St. Peter's did Bramante design a coherent building program for the Vatican—a program which comprised the Stanze, the Loggie, and the Sistine Chapel, but which required awkward changes in the fragmentary Cortile del Belvedere. After a hectic start, this project was also abandoned during the last three years of Julius' reign. ${ }^{21}$

Julius' contributions to Roman urbanism were similarly lacking in coherence. They started, understandably, only after the large Vatican projects were realized but in a no less arbitrary manner. In October I 508 , the pope planned "infinite changes," one of them being a huge palace for the different Roman lawcourts which was to be built on a new square opposite Rodrigo Borgia's palace, the Cancelleria Vecchia. Houses, shops, and a church worth 40,000 ducats were to be destroyed without compensation in the construction of this project. The plan was Bramante's famous Palazzo dei Tribunali, the first real office building since ancient Rome. This attempt to centralize administration and the

20 Idem, "Capella Iulia," 60-6r; Ackerman, The Cortile del Belvedere (Vatican, I954); Arnaldo Bruschi, Bramante architetto (Bari, 1969), 291-434, 865-882; Frommel, "Lavori architettonici di Raffaello in Vaticano," in idem et al., Raffaello architetto, 357.

21 Frommel, "Capella Iulia," 26-27; idem, "Il Palazzo Vaticano," I22-I32. 


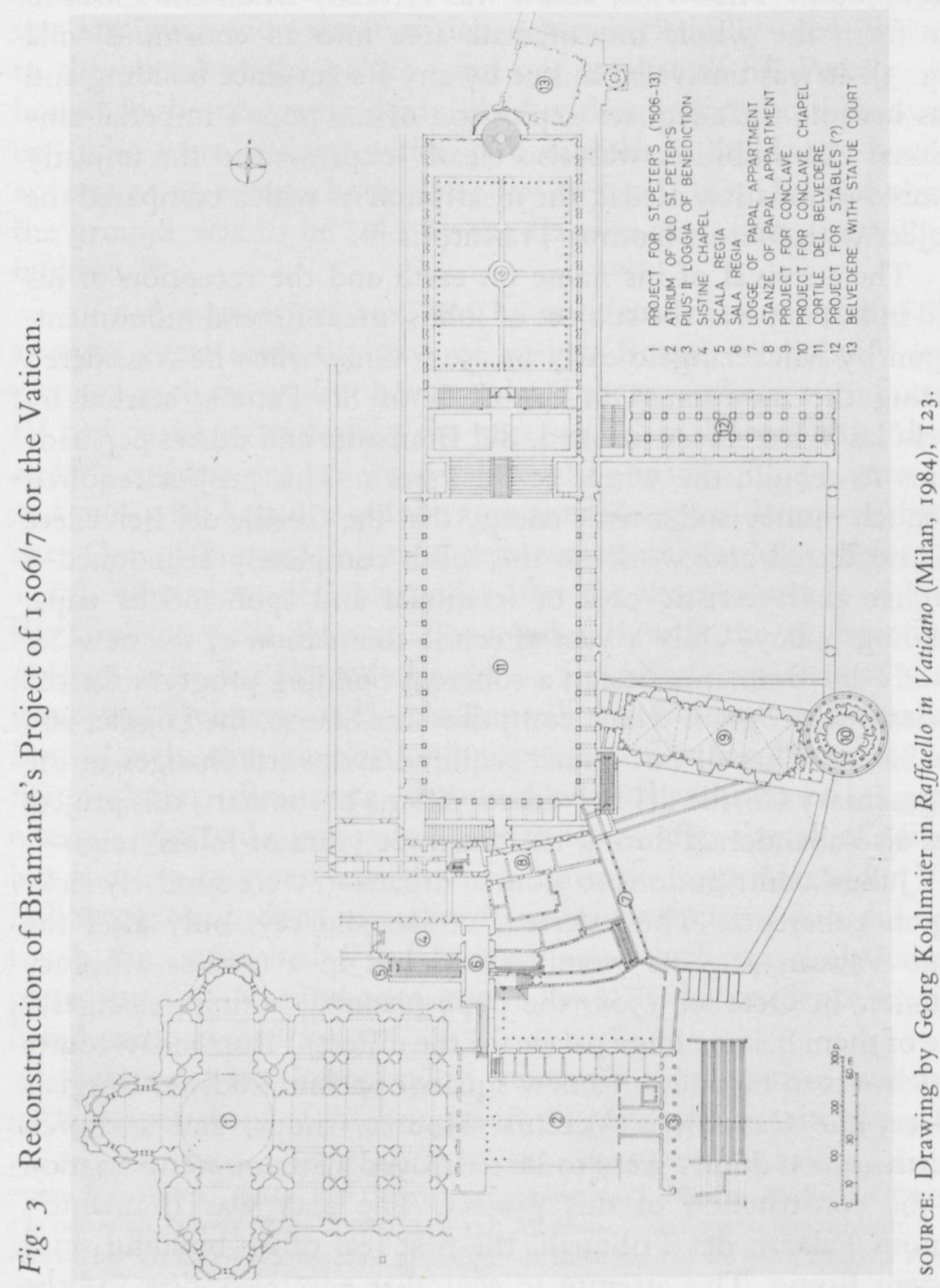


different lawcourts was hardly acceptable to the old republicans who jealously guarded the few privileges left to them. This may have been one of the reasons why Julius abandoned the project after two or three years. Only in I694 was it taken up in the Curia Innocenziana on Monte Citorio. ${ }^{22}$

But Julius II would not have been a product of his time had he planned this urban renewal without any egocentric intention. The old palazzo of the detested Rodrigo Borgia had become the residence of his nephew, Cardinal Sisto della Rovere. The new square between the two palaces, had the project been realized, would have become a Forum Iulium. Once more the memory of the Borgias would have been replaced by the imperial splendor of Julius and his family. Julius wanted also to rebuild Nero's Pons Triumphalis as his uncle Sixtus had rebuilt the bridge of Marcus Aurelius, both worthy successors of the Roman pontifices Maximi. For the transformation of Via Giulia into one of Rome's most prestigious streets potential patrons of churches and palaces were sought. One of the smaller side streets was filled with simple but standardized row-houses-a system which has made Via Giulia, even without Forum Iulium, a great urban success even today.

On the other side of the Tiber, Bramante traced a nearly parallel street, the Via della Lungara, which connected the Vatican with Trastevere and the main harbor. Although it was not protected by walls, it attracted wealthy and sophisticated patrons such as Agostino Chigi, Raffaele Riario, Alberto Pio da Carpi, Filippo Adimari, and Baldassarre Turini who built suburban palaces and villas along the new street. People felt safer under the great Julius and longed for a "vita in villa" even in their permanent urban residences. Many of the new buildings of both Via della Lungara and Via Giulia overlooked the river (Farnesina, Palazzo dei Tribunali, Palazzo Farnese, San Eligio, and San Giovanni dei Fiorentini, among others), which thus became part of the urban system and was used by the pope himself when he went by boat to Ostia or to the Magliana (Fig. 4 ). ${ }^{23}$

22 Spezzaferro, "La politica urbanistica dei Papi e le origini di via Giulia," in Luigi Salerno, Spezzaferro, and Tafuri, Via Giulia (Rome, I973), 58-64, 314-322.

23 Frommel, Die Farnesina und Pereuzzis architektonisches Frühwerk (Berlin, I96I), 163I70; Emanuel Rodocanachi, La première Renaissance: Rome au temps de Jules II et de Léon X (Paris, I9I2), 93. 
Fig. 4 Town Planning of Rome under Pope Julius II.

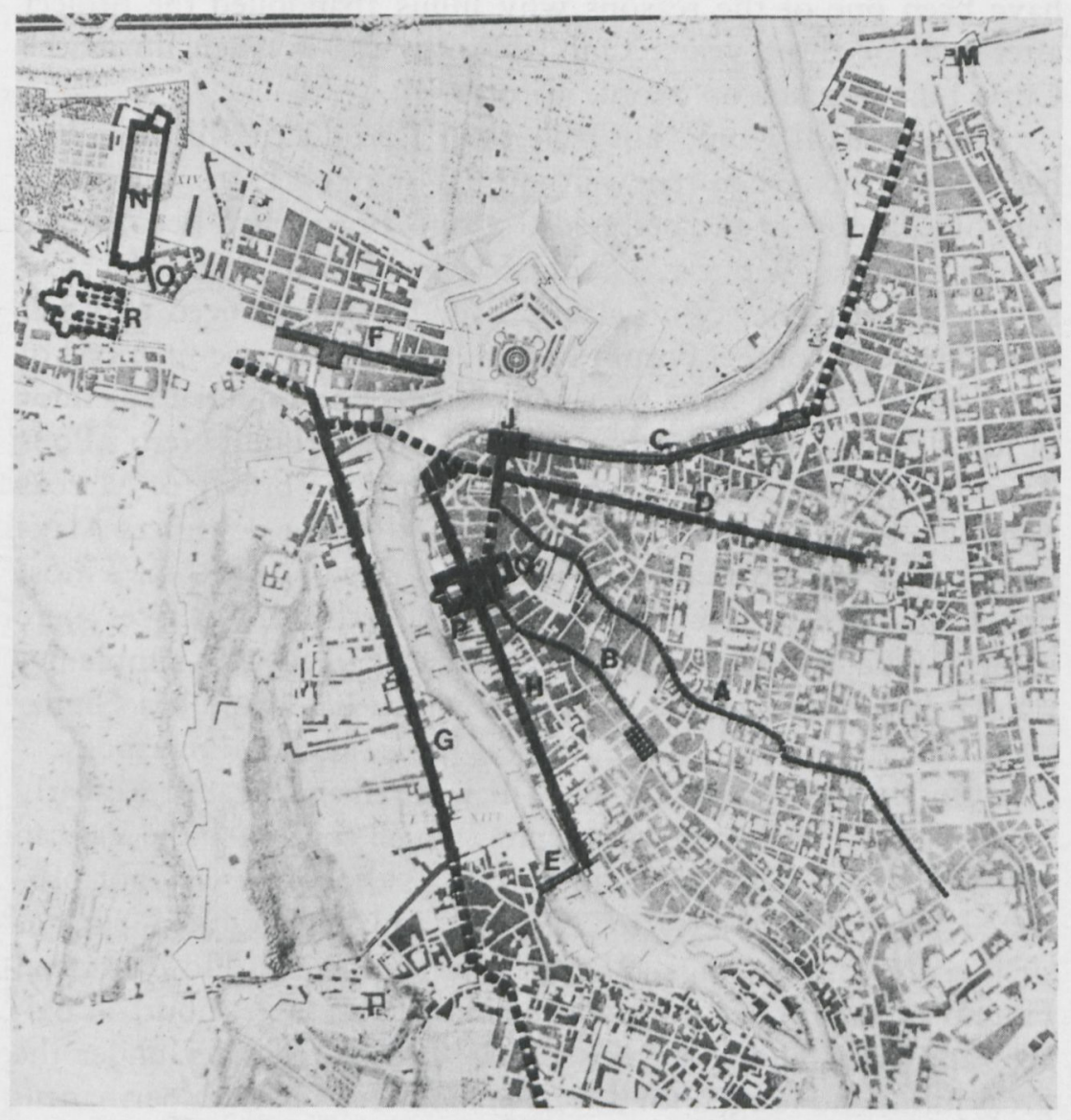

The main streets of Rome in the fifteenth century A Via Papale

B Via Florea and Campo di Fiori

The innovations of Sixtus IV (147I-I 484)

C Via Sistina

D Via Recta

E Ponte Sisto

The innovations of Alexander VI (1492-1 503)

F Via Alessandrina

The innovations of Julius II (1503-I5I3) and of Bramante

The executed innovations

G Via della Lungara

$\mathrm{H}$ Via Giulia

I Piazza and Canale di Ponte

L Via di Ripetta

M Apse of Santa Maria del Popolo

N Cortile del Belvedere

O Logge Vaticane

The planned but unrealized innovations

P Palazzo dei Tribunali

Q Enlargement of the old Cancelleria

R St. Peter

SOURCE: Map by Manfredo Tafuri in Frommel et al., Raffaello Architetto (Milan, 1984), 69. 
Little wonder then that Julius' successor, the young Leo X, changed building policy again, if only to show that he was a Medici. Leo was a great diplomat and connoisseur, but not as powerful a leader and patron as Julius had been. But only under Leo did Roman Renaissance architecture reach its first climax. Julius had burdened Bramante almost exclusively with all important commissions. Most of Julius' building activity was concentrated on the Vatican area and only a few outstanding buildings were not designed by Bramante. By I5I3/I4, after Julius' death, Bramante's assistants and pupils had become independent; each of them, not only Raphael and Antonio da Sangallo, but also Giuliano da Sangallo, Baldassare Peruzzi, Andrea Sansovino, and, from about I5I8 onward, Jacopo Sansovino and young Giulio Romano also took part in new building activities. Cardinals as well as prelates, patricians, lawyers, doctors, rich artists, and, above all, young Roman patricians, who by now had become conscious of their past, began to build small but highly sophisticated palazzetti. Associations comprising inhabitants of single towns or countries, such as the Florentines, the French, the Spanish, and the Sienese; guilds, such as the goldsmiths, the bakers, and the carpenters; and devotional confraternities all started to build their own churches and oratories. In a few years Rome began to acquire an urban character which it had previously lacked. If we look at the first realistic views of Renaissance Rome, be it that of the Codex Escurialiensis of about I 500 or those of the I 530 os, antique ruins and medieval campaniles as well as towers of noble families and new building fragments rise in isolation above a sea of small and miserable houses, most of them not more than four or five meters high. Only during the eighteenth and nineteenth centuries did Rome acquire the coherent texture that we admire today. But Leo X and his talented architects doubtless appreciated their contemporary problem and tried to solve it. ${ }^{24}$

Much less successful were Leo's own projects. His first initiative in $15 \mathrm{I} 3$ was to double the dimension of the already monumental Julian project for the new St. Peter's and to use much more travertine and marble than his economical predecessor had proposed. Thus the costs rose so enormously that at the end of

24 Hermann Egger, Römische Veduten (Vienna, 193I), II, pl. 104, I05, 106, 107; Richard Krautheimer, Roma Alessandrina: The Remapping of Rome under Alexander VII (Poughkeepsie, N.Y., 1982). 
Leo's pontificate work had hardly proceeded and many doubted whether it would ever be finished. Leo's tendency to enrich and thus appropriate the projects of his predecessor succeeded only on a smaller scale, as in the Vatican Loggie which Raphael transformed into a luxurious "Gesamtkunstwerk." In order to give Via Giulia a new center of gravity and a new meaning, Leo replaced Julius' Palazzo dei Tribunali with the pantheon-like church of San Giovanni dei Fiorentini at its northern end. Raphael himself, although not a Florentine, wanted to build his new palace opposite this new church, and Antonio da Sangallo the Younger his next to it, the only one of these projects to be realized. The southern end of Via Giulia acquired a new focus with the palace of Cardinal Alessandro Farnese, an old friend and recent relative of Leo. From its inception in I5I4 it was meant to be the seat of the rising Farnese dynasty, with two apartments for Alessandro's two sons, and probably also two facades: the present one oriented toward Via Arenula and another toward the new Via Giulia. Its architect, Sangallo, was largely inspired by Bramante's abortive project for the Palazzo dei Tribunali, which Sangallo himself had helped to prepare. ${ }^{25}$

Even more illuminating for Leo's building policy was the new Via Ripetta (Fig. 5). It was the fourth straight street ruthlessly cut through the old Roman city since I499. Its northern part had already been started under Julius, probably in order to provide a worthy access to his favorite church of Santa Maria del Popolo. It was certainly a happy accident that the fifteenth-century Roman residence of the Medici, the actual Palazzo Madama and Senate, was situated very close to the southern extension of Via Ripetta. Since Palazzo Madama was flanked on one side by the Roman university, the old Sapienza, and Palazzo Lante, the new house of Leo's sister-in-law, and on the other by the French national church, Luigi dei Francesi, Leo's architects had the opportunity to counterbalance Piazza del Popolo and its della Rovere church with an even more important and glorious Medicean center. ${ }^{26}$

25 Frommel, "Lavori architettonici," 368; Tafuri, "Roma instaurata," 94-98; Frommel, Der römische Palastbau, II, 265, 3I8; idem, "Raffael und Antonio da Sangallo," 264-266; idem, "Sangallo et Michel-ange (I5I3-1550)," in Le Palais Farnèse, I, I, I28-129.

26 Tafuri, "Roma instaurata," 82-88. 


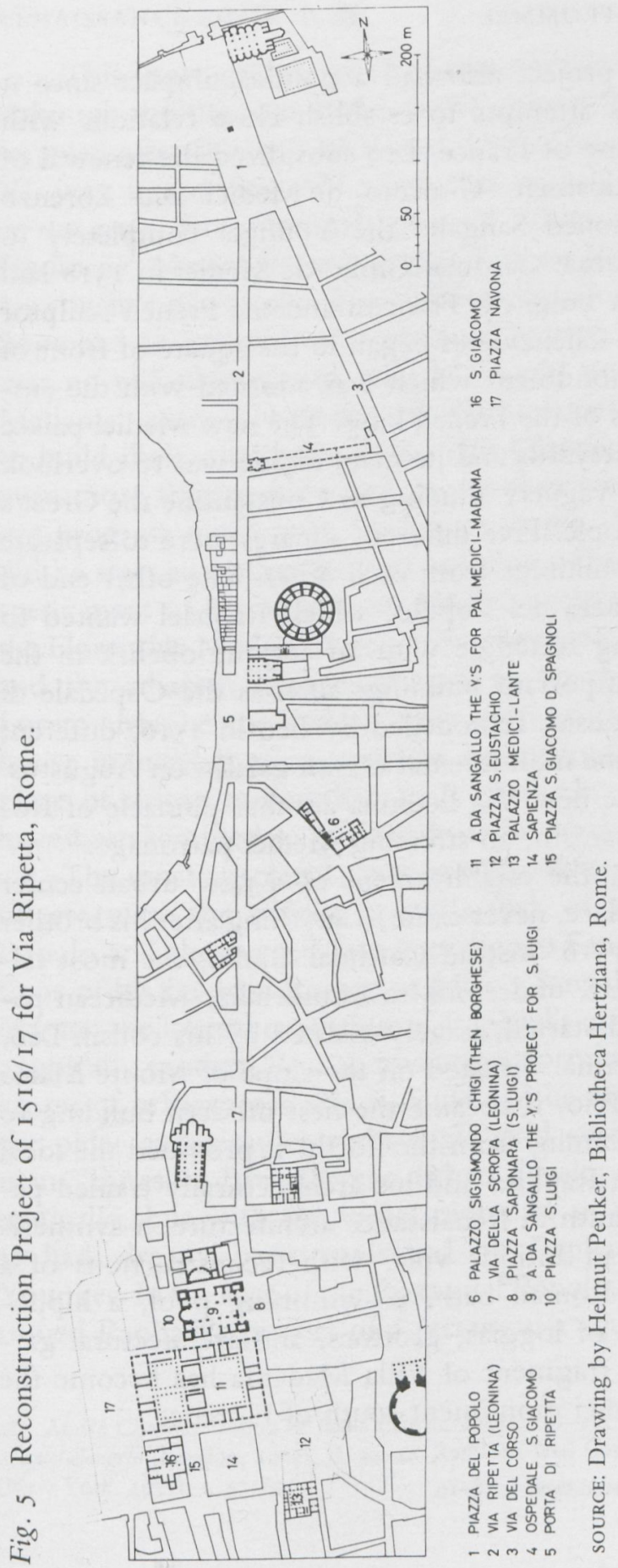


This ambitious project also had a political impact since it coincided with Leo's attempts to establish close relations with Francis I and the house of France. Leo subsidized the renewal of the Sapienza; his kinsmen, Giuliano de'Medici and Lorenzo de'Medici, commissioned Sangallo the Younger completely to rebuild Palazzo Madama; Cardinal Giulio de'Medici in I5 I 8 laid the first stone of San Luigi dei Francesi and the French sculptor and architect Jean de Chenevières began in the square of front of San Luigi a round monument which was adorned with the emblems and the virtues of the French king. The new Medici palace was to have two courtyards and its main façade was to overlook Piazza Navona, thus vaguely alluding to Constantine the Great's palace in Constantinople. Five different squares were to separate these splendid new buildings from each other. The other end of the road led into Piazza del Popolo, which Raphael wanted to transform into a long rectangle with an antique obelisk in the center. A series of important buildings such as the Ospedale di San Giacomo in Augusta, remodelled by Leo in I 516 , different private palaces, and the monumental Orsini garden on Augustus' Mausoleum made the new Via Leonina another pinnacle of Roman Renaissance urbanism, all stressing Medici patronage. ${ }^{27}$

Leo's main aim, the establishment of a new urban center around the Medici palace, never came to anything after his brother Giuliano's death in I5I6. Instead Cardinal Giulio, the most talented of all the Medici, undertook to immortalize Medicean patronage in Rome and started, largely assisted by his cousin Leo, the grand Villa Madama. Situated on the slope of Monte Mario just above Ponte Milvio, it became the first modern building to be seen by visitors coming from the north. It provided the ideal opportunity for both Raphael and his architecturally trained patron to realize the zenith in Renaissance architecture, a synthesis of a Medicean and an antique villa, with reconstructions of a Roman theater and Roman bath, a swimming pool, a hippodrome, and all sorts of loggias, grottoes, and architectural gardens. The surviving fragment of Villa Madama has become the most impressive Medici monument south of Florence.

27 Frommel, Der römische Palastbau, I, I8-I9. 
This short golden age of architecture ended with Leo's death, although multifarious building activities of a high standard went on even after the sack of Rome. Leo's Dutch successor, Hadrian VI, was, in the view of Leo's artists, rightly regarded an "enemy of the arts." But, strangely enough, when, after only two years, Giulio de' Medici became pope Clement VII, he did not resume his cousin's patronage. The political situation was critical and the pope had to concentrate on serious matters. Nevertheless, there was no plausible reason why he should not have finished Villa Madama; many subsequent counterreformation popes found ways to build their own huge villas. But Clement VII left its exterior even more fragmentary and poorer than we see it today. He did not progress much with St. Peter's or the Vatican buildings; nor did he start any other Roman building of importance. Instead he spent most of his money on Michelangelo's various projects for the Florentine Medici church of San Lorenzo, with its tomb chapel and the adjacent library, as well as on the pilgrim church of Loreto. Maybe the sudden extinction of the secular line of his house induced him to look for its survival in stone near to its place of origin rather than in Rome, where a successor would have been tempted to overshadow the Medici achievement. ${ }^{28}$

The most spectacular urban achievements of Clement's pontificate were the tridente (a triple fork of streets) of Piazza del Popolo and the curved facade of Banco San Spirito, both inventions of his favorite Roman architect, Sangallo the Younger. The tridente, the logical extension of Raphael's earlier little bidente, was a typically modern Roman invention, forming as it did a radiating center of urban areas which could not be organized according to the older and simpler right-angle grid system. It was repeated many times in later Roman urban development, not just schematically, but with the visual center of an obelisk or a fountain as had already been envisaged by Raphael and Sangallo the Younger. In the case of the Piazza del Popolo, however, the tridente ruined Raphael's project of a rectangular square and made it dif-

28 André Chastel, Il sacco di Roma (Turin, 1983), 12I-I22; Ackerman, The Architecture of Michelangelo (London, 1964), II, 22-42; Kathleen Weil Garris, The Santa Casa di Loreto (New York, I977), I, 57-89. 
ficult for subsequent planners to give the piazza a new and coherent shape. ${ }^{29}$

The increasing tendency of Rome's architects to conceive of the city's urban planning in visual terms was even more obvious in the concave façade of the former Zecca, the Banco San Spirito. It was perhaps the first façade completely independent from the building behind it-a sort of triumphal arch for Clement VII and for the pilgrims who would mark the forthcoming holy year of I525. As such it was to be the visual apex for anyone coming from Ponte Sant' Angelo and moving to Via del Governo Vecchio, the old Via Papalis, or Via dei Banchi Vecchi. The façade was built by Clement's cunning chamberlain, Francesco Armellini, with taxes raised from his neighbors. Since Armellini owned the older house behind the façade, we can be sure that he did not improve it simply out of veneration for his master. ${ }^{30}$

If the further decline of Clement's Roman building activities after 1527 is often said to be a consequence of the sacking of Rome, his successor, Paul III Farnese (I534-I 549), proved how rapidly the situation could change for the better. Paul, who was eight years older than Clement, had also lived for some time in the circle of Lorenzo il Magnifico, and his two favorite architects were also Sangallo the Younger and Michelangelo. Until his election he had exclusively employed Sangallo, whom he had already discovered in I 5 I 3 and who had built not only the family palace but many other important buildings throughout the Farnese territory around Lake Bolsena. Whereas Clement's patronage was mainly oriented toward his native Florence and favored commemorative rather than dynastic projects, Paul was a conscious Roman. Immediately after his election he buttressed his power as pope, as lord of Rome, and as head of the Farnese dynasty in a manner comparable only to Julius II to whom Paul, as Cardinal Alessandro Farnese, had been quite close. His new approach was most evident in his first building, the Torre Paolina, which he built in I 535 on the site of the antique Capitoline arch, next to Santa Maria in Aracoeli. This fortified villa served as airy adjunct and belvedere of the Palazzo Venezia, which Paul III used as his 
summer residence, the first pope to do so since the time of its builder, Paul II. It was connected by a viaduct, although a much simpler one than the Via Julia between the Vatican palace and its belvedere. Paul's next step in appropriating the Capitol was to transfer the statue of Marcus Aurelius from the Lateran in I 538. The inscriptions on its new pedestal made it clear that this emperor had been Rome's wise lord and that the pope was his legitimate successor. The outline of Michelangelo's monumental project for the area capitolina may already have been conceived by this date. ${ }^{31}$

At about the same time as the Torre Capitolina was being built, Paul commissioned the replanning of St. Peter's. Probably at Paul's request all projects envisaged a centralized plan which Julius II had given up for religious as well as functional reasons. Since the time of Nicholas V, and even since Julius II, attitudes had changed; the formal aspect of architecture had become much more important and St. Peter's was regarded more and more as an architectural monument. The aesthetic effect, which was meant to be increased by its centralization, became nearly as important as its functional one. This formalistic tendency was even increased when Paul authorized Michelangelo to destroy a good deal of what had been built before, including some of the functionally important secondary rooms, and to reshape the exterior into a unified sculptural body. ${ }^{32}$

In I 537 Paul founded a Farnese duchy for his son Pierluigi Farnese and commissioned Sangallo to build Castro, its new capital. The result was, before its destruction, perhaps less impressive than Rossellino's Pienza. Politically, however, it became the embryo of a new European dynasty, and the fulfillment of Alessandro Farnese's lifelong dreams. ${ }^{33}$

3I Giovannoni, Antonio da Sangallo il Giovane (Rome, I959), I, I 50-169, 210-214; Frommel, "Raffael und Antonio da Sangallo," 269; Jacob Hess, "Die päpstliche Villa bei Araceli: Ein Beitrag zur Geschichte der kapitolinischen Bauten," in Miscellanea Bibliothecae Hertzianae (Munich, I96I), 239-254; Ackerman, Michelangelo, II, 50-5I; Frommel, Michelangelo und Tommaso dei Cavalieri (Amsterdam, 1979), 80.

32 Ackerman, Michelangelo, II, 85-95; Frommel, "Die Peterskirche unter Papst Julius II im Licht neuer Dokumente," Römisches Jahrbuch für Kunstgeschichte, XVI (1976), 89; idem, "Capella Iulia," $5 \mathrm{I}-60$.

33 Hildegard Giess, "Die Stadt Castro und die Pläne von Antonio da Sangallo dem Jüngeren, II,” in Römisches Jahrbuch für Kunstgeschichte, XIX (I98I), 85-I40. 
The other symbol of Paul's dynastic ambition, the Roman Palazzo Farnese, was continued in its original dimensions only after I 540. Sangallo transformed its interior into a "palazzo non più da Cardinale, ma da Pontefice" (no longer a cardinal's palace, but a pope's). For the same reason a huge regular piazza was laid out in front of it, as large as the palace itself and bigger than any such piazza before. Its main axis was extended to the Via Papalis and, according to Michelangelo's plan of I546, it would have continued across the garden and a new bridge, up to the Farnese vineyard in Trastevere. Most of it was paid for by the Apostolic Chamber, although neither Castro nor the Palazzo Farnese were meant to be papal property. This new emphasis on a longitudinal axis even in the more private sphere of the Farnese gardens is another illuminating symptom of formalization in Roman urbanism. This axis was not important for improving the traffic flow, as had been the aim of the Via Alessandrina, the Via Giulia, and the Via Ripetta; it was meant to impress people (Fig. 6). ${ }^{34}$

This high degree of formalization was even more evident in Michelangelo's monumental project for the Capitol, which he may already have designed for Paul, but which was executed only after I 560 . For Michelangelo it was no longer sufficient to counterbalance existing buildings with new ones, as had been the case in all earlier Roman squares; to distinguish the different functions and significance of two lateral palaces as Rossellino had done in Pienza; or to envelop preexisting structures with surrounding porticoes as in Vigevano or Ascoli Piceno. Michelangelo reshaped the two existing buildings and, primarily for reasons of symmetry, added a third which was to house the Sala del Consiglio. Thus he created, more impressively than had anyone before, the image of hierarchically organized power. A new street, the actual Via Capitolina, led axially to the ramp. Already climbing up this ramp one feels grandeur and elevation. Once on the square the eyes progressively are led to the dominant Palazzo dei Senatori. In its central loggia planned by Michelangelo, the senator, as the pope's vicar, was to appear to the obedient crowd. ${ }^{35}$

34 Frommel, "Sangallo et Michel-Ange," I45-174; Giorgio Vasari (ed. Gaetano Milanesi), Le vite de' piu eccellenti pittori scultori ed architettori (Florence, 1880), V, 469-470; Frommel, Palazzi Romani del Rinascimento.

35 Harmen Thies, Michelangelo: Das Kapitol (Munich, I982), 216-236. 
RENAISSANCE ROME | 63

Fig. 6 Michelangelo's Reconstruction Project around Palazzo Farnese.

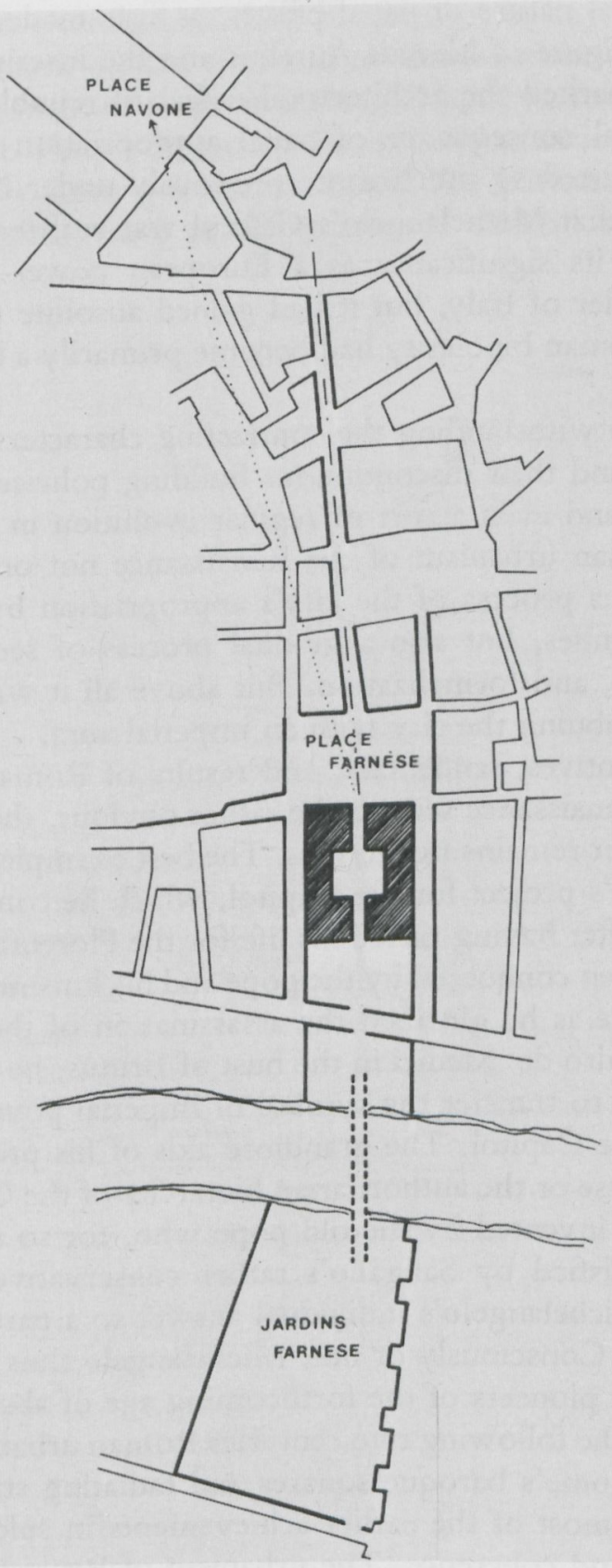

SOURCE: Map by Luigi Spezzaferro in Le Palais Farnèse (Rome, I98I), I, I, I20, Fig. Io. 
Each individual element of Michelangelo's project stressed the hierarchical nature of papal power, as was made explicit by the imperial figure of Marcus Aurelius and the inscription on its pedestal. It marked the architectural defeat of republican autonomy, the final consequence of papal appropriation of the city which had started so much more cautiously under Nicholas V. By the time that Michelangelo's Capitol was realized, the Holy See had lost its significance as a European power and as the potential unifier of Italy, but it had gained absolute power over its capital. Roman bipolarity had become primarily a formal phenomenon.

Thus, notwithstanding the contrasting characters of Renaissance popes and their discontinuous building policies, there was a continuity and even a sort of regular evolution in Roman urbanism. Roman urbanism of the Renaissance not only reflected the continuous process of the city's appropriation by the popes and their families, but also a gradual process of secularization, beautification, and formalization. But above all it was a gradual process of embuing the city with an imperial aura.

If the motives, tendencies, and results of Roman urbanism during the Renaissance seem to be rather obvious, their transformation into art remains mysterious. The best example, again, was Michelangelo's project for the Capitol, which he conceived only a few years after having risked his life for the Florentine republic, which was thèn conquered by the pope and his kinsmen. At about the same time as he glorified the assassination of the Florentine duke Alessandro de' Medici in the bust of Brutus, he had to obey the pope and to transfer the symbol of imperial power from the Lateran to the Capitol. The grandiose axis of his project for the Palazzo Farnese or the authoritarian hierarchy of the Capitol were certainly not invented by the old pope who, for so many years, had been satisfied by Sangallo's rather conservative structures; they were Michelangelo's individual answer to a particular papal commission. Consciously or not, Michelangelo thus became one of the artistic pioneers of the forthcoming age of absolutism.

During the following two centuries Roman urbanism reached its climax. Rome's baroque squares and radiating street systems overshadow most of the earlier achievements in splendor, monumentality, and coherence. The urbanism of Renaissance Rome, so overwhelming in its final result, reflects not only the classic- 
style grandeur of the popes, but also their egocentric spontaneity, their will to overshadow their predecessor at any cost, to print their own mark on the city, and to eternalize the glory of their family. But most of these monumental squares, from Piazza Navona and St. Peter's Square to Piazza Sant' Ignazio and Piazza di Spagna, now have a religious focus. The patron himself is no longer glorified, save as the patron as faithful subject of the church. 